\title{
Air-sea exchange of gaseous mercury in the tropical coast (Luhuitou fringing reef) of the South China Sea, the Hainan Island, China
}

\author{
Zhijia Ci $^{1} \cdot$ Xiaoshan Zhang ${ }^{1} \cdot$ Zhangwei Wang $^{1}$
}

Received: 31 August 2015 / Accepted: 23 February 2016 / Published online: 2 March 2016

(C) Springer-Verlag Berlin Heidelberg 2016

\begin{abstract}
The air-sea exchange of gaseous mercury (mainly $\mathrm{Hg}(0))$ in the tropical ocean is an important part of the global $\mathrm{Hg}$ biogeochemical cycle, but the related investigations are limited. In this study, we simultaneously measured $\mathrm{Hg}(0)$ concentrations in surface waters and overlaying air in the tropical coast (Luhuitou fringing reef) of the South China Sea (SCS), Hainan Island, China, for 13 days on January-February 2015. The purpose of this study was to explore the temporal variation of $\operatorname{Hg}(0)$ concentrations in air and surface waters, estimate the air-sea $\operatorname{Hg}(0)$ flux, and reveal their influencing factors in the tropical coastal environment. The mean concentrations $( \pm \mathrm{SD})$ of $\mathrm{Hg}(0)$ in air and total $\mathrm{Hg}(\mathrm{THg})$ in waters were $2.34 \pm 0.26 \mathrm{ng} \mathrm{m}^{-3}$ and $1.40 \pm 0.48 \mathrm{ng} \mathrm{L}^{-1}$, respectively. Both $\mathrm{Hg}(0)$ concentrations in waters $\left(53.7 \pm 18.8 \mathrm{pg} \mathrm{L}^{-1}\right)$ and $\mathrm{Hg}(0) / \mathrm{THg}$ ratios (3.8\%) in this study were significantly higher than those of the open water of the SCS in winter. $\mathrm{Hg}(0)$ in waters usually exhibited a clear diurnal variation with increased concentrations in daytime and decreased concentrations in nighttime, especially in cloudless days with low wind speed. Linear regression analysis suggested that $\mathrm{Hg}(0)$ concentrations in waters were positively and significantly correlated to the photosynthetically active radiation (PAR) $\left(R^{2}=0.42, p<0.001\right)$. Surface waters were always supersaturated with $\operatorname{Hg}(0)$ compared to air (the degree of saturation, 2.46 to 13.87), indicating that the surface water was one of the atmospheric $\operatorname{Hg}(0)$ sources. The air-sea $\operatorname{Hg}(0)$ fluxes were
\end{abstract}

Responsible editor: Gerhard Lammel

Zhijia Ci

zjci@rcees.ac.cn

1 Research Center for Eco-Environmental Sciences, Chinese Academy of Sciences, No. 18 Shuangqing Road, Beijing 100085, China estimated to be $1.73 \pm 1.25 \mathrm{ng} \mathrm{m}^{-2} \mathrm{~h}^{-1}$ with a large range between 0.01 and $6.06 \mathrm{ng} \mathrm{m}^{-2} \mathrm{~h}^{-1}$. The high variation of $\mathrm{Hg}(0)$ fluxes was mainly attributed to the greatly temporal variation of wind speed.

Keywords Elemental Hg $\cdot$ Air-sea Hg exchange $\cdot$ Emission flux $\cdot$ Tropical coast $\cdot$ South China Sea $\cdot$ China

\section{Introduction}

The ocean plays an important role in the global mercury $(\mathrm{Hg})$ cycle because it is both a source and a sink for atmospheric $\mathrm{Hg}$ (Mason et al. 2012). Over the past three decades, many studies have been performed to investigate the oceanic $\mathrm{Hg}$ biogeochemistry (Fitzgerald et al. 2007 and references therein). Studies suggest that the reduction of divalent $\mathrm{Hg}$ ( $\mathrm{Hg}$ (II)) to elemental $\mathrm{Hg}(\mathrm{Hg}(0))$ and oxidation of $\mathrm{Hg}(0)$ to $\mathrm{Hg}(\mathrm{II})$ (i.e., $\mathrm{Hg}$ redox chemistry) in waters can occur simultaneously and is regulated by both photochemical process and microbial process and the photoreduction of $\mathrm{Hg}(\mathrm{II})$ is the primary pathway for the production of $\operatorname{Hg}(0)$ (Amyot et al. 1997; Lanzillotta et al. 2002; Rolfhus and Fitzgerald 2004; Whalin et al. 2007; Qureshi et al. 2010; Ci et al. 2016). Factors influencing the $\mathrm{Hg}$ redox chemistry in the marine environment include the $\mathrm{Hg}$ concentration and speciation in water, the strength and spectrum of solar radiation, the concentration and structure of dissolved organic matter and suspended particulate matter, salinity, biological activity, and so on (Qureshi et al. 2012; Ci et al. 2016). Field observations showed that water $\operatorname{Hg}(0)$ concentrations in waters of oceans and seas were highly variable both spatially and temporally, and surface waters were supersaturated with $\mathrm{Hg}(0)$ compared to air in most study time and regions (Qureshi et al. 2012 and references therein). 
The tropical ocean is an important part of the global ocean system. This marine system is characterized by high solar radiation and water temperature, inducing special biogeochemistry of trace elements (Fitzgerald et al. 1984; Christian et al. 2001). Currently, most of investigations on the air-sea $\mathrm{Hg}(0)$ exchange were conducted in the temperate (Mason et al. 1995, 1999; Lanzillotta et al. 2002; Gårdfeldt et al. 2003; Andersson et al. 2007; Fantozzi et al. 2007, 2013; Kuss and Schneider 2007; Ci et al. 2011a, d, 2015; Soerensen et al. 2013) and polar (Mason et al. 1995; Andersson et al. 2008b) marine environments. Only a few measurements focused on tropical oceans and seas (Kim and Fitzgerald 1986; Mason and Fitzgerald 1993; Fu et al. 2010; Kuss et al. 2011; Tseng et al. 2012, 2013; Soerensen et al. 2014). Particularly, the investigation focused on the Hg biogeochemistry in the tropical coastal environment is poor.

Over the last two decades, $\mathrm{Hg}$ biogeochemistry in coastal marine environments is receiving increasing attention (Mason et al. 1999; Ferrara et al. 2000; Lanzillotta et al. 2002; Gårdfeldt et al. 2003; Rolfhus and Fitzgerald 2004; Andersson et al. 2007; Fantozzi et al. 2007; Ci et al. 2011a, c). Due to its unique physicochemical properties, the coastal marine ecosystem is considered as an important reactor for rapid, significant, and complicated biogeochemistry of $\mathrm{Hg}$ (Fitzgerald et al. 2007). In this study, we simultaneously measured the $\operatorname{Hg}(0)$ concentrations in surface water and overlaying air in a typical tropical coast of the South China Sea (SCS), Hainan Island, China, and further estimated the air-sea $\mathrm{Hg}(0)$ fluxes using a two-layer exchange model. Environmental parameters (e.g., solar radiation, wind speed, and water temperature) affecting the $\operatorname{Hg}(0)$ dynamics are discussed. This study increases the dataset of the global ocean $\operatorname{Hg}(0)$ flux and advances the knowledge of $\mathrm{Hg}$ biogeochemistry in the tropical marine environment.

\section{Experimental methods}

\section{Site description}

The study was performed from 27 January to 8 February 2015 at the Tropical Marine Biological Research Station of the South China Sea Institute of Oceanology, Chinese Academy of Sciences. This station is located at the Luhuitou of Sanya City, the southern tip of Hainan Island, China $\left(18^{\circ}\right.$ $12.71^{\prime} \mathrm{N}, 109^{\circ} 28.39^{\prime} \mathrm{E}$; Fig. 1). This coastal region is characterized by a wide distribution of coral reef and mainly receives offshore water from the open water of the SCS (Zhang et al. 2013). The wet and warm southwest monsoon from a low-latitude ocean prevails during April to September, and the dry and cold northeast monsoon from continental East Asia predominates during October to the following March.

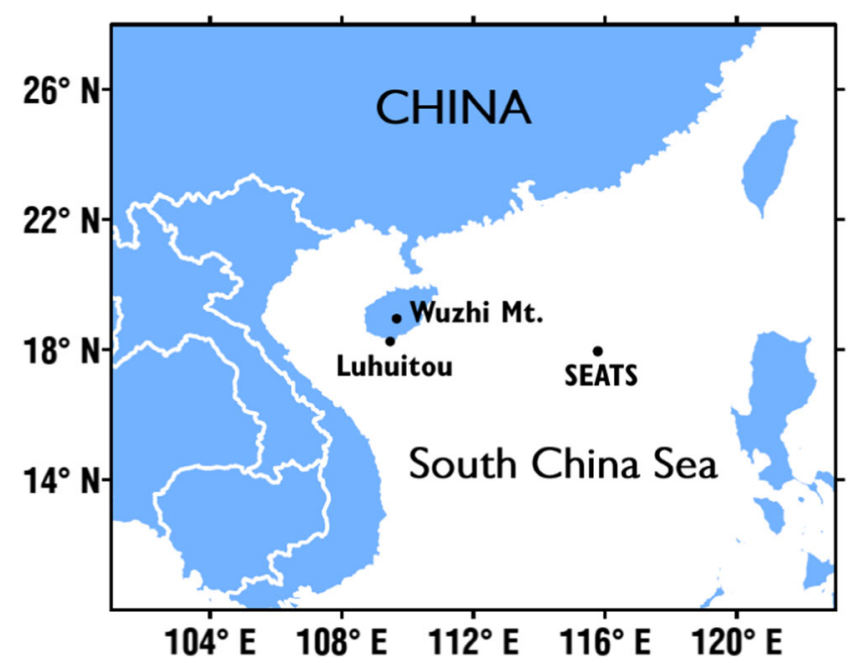

Fig. 1 The location of the sampling station (Luhuitou) and the surrounding marine environment

\section{Sampling, analysis, and measurement}

The details and quality assurance/quality control for determination of $\mathrm{Hg}(0)$ and total $\mathrm{Hg}(\mathrm{THg})$ in water are given in our previous studies (Ci et al. 2011a, c). Briefly, the water samples were manually collected from the sea surface and purged with $\mathrm{Hg}$-free air. The released $\mathrm{Hg}(0)$ was collected on a gold trap and was quantified by a cold vapor atomic fluorescence spectrophotometer (model III, Brooks Rand, USA) using the twostage gold amalgamation method. After $\mathrm{Hg}(0)$ collections, the subsamples were used to determine the remaining $\mathrm{THg}$, following Gill and Fitzgerald (1987) and the USEPA Method 1631 (USEPA 2002). Briefly, 100-mL samples were oxidized with $\mathrm{BrCl}$ and $\mathrm{NH}_{2} \mathrm{OH}$ pre-reduction, $\mathrm{SnCl}_{2}$ reduction, $\mathrm{Hg}$ free air purging, gold trap pre-concentration, thermal desorption, and cold vapor atomic fluorescence spectrophotometry (CVAFS) quantification.

Atmospheric $\operatorname{Hg}(0)$ was measured at the station following the Method IO-5 of USEPA (1999). The principle of this method is also the two-stage gold amalgamation and CVAFS determination. For a typical measurement, the ambient air was delivered to the gold trap with a flow rate of $1.0 \mathrm{~L} \mathrm{~min}{ }^{-1}$ for 2 to $3 \mathrm{~h}$ through a Teflon tube. A $47-\mathrm{mm}$ diameter Teflon pre-filter was placed in the inlet to remove the particle matter (including particulate $\mathrm{Hg}$ ). This measurement was considered as that of atmospheric $\mathrm{Hg}(0)$ (Ci et al. 2011d; Tseng et al. 2012; Gustin et al. 2015).

The $\mathrm{Hg}$ analysis system was calibrated using a gastight micro-syringe to inject $\mathrm{Hg}(0)$-saturated air from water bath, and the analytical precision was $<2 \%(\mathrm{Ci}$ et al. 2011a). The method detection limit (three times the standard deviations of system blanks) for $\mathrm{Hg}(0)$ and $\mathrm{THg}$ in waters and $\operatorname{Hg}(0)$ in the atmosphere was $3.0 \mathrm{pg} \mathrm{L}^{-1}$, $0.10 \mathrm{ng} \mathrm{L}^{-1}$, and $0.05 \mathrm{ng} \mathrm{m}^{-3}$, respectively. 
The related environmental parameters, including the photosynthetically active radiation (PAR), water temperature, and wind speed, were monitored with the corresponding sensors (Ci et al. 2011a).

\section{Model for air-sea $\mathrm{Hg}(0)$ flux}

The details about the calculation of air-sea $\operatorname{Hg}(0)$ flux and the uncertainties and limitations of this method are given in our previous studies (Ci et al. 2011a, d). Briefly, the air-sea $\mathrm{Hg}(0)$ exchange flux $(F)$ is calculated by $F=K\left(\operatorname{Hg}(0)_{\text {water }}-\mathrm{Hg}(0)_{\text {air }}\right.$ / $H^{\prime}$ ), where $F\left(\mathrm{ng} \mathrm{m}^{-2} \mathrm{~h}^{-1}\right)$ is the $\mathrm{Hg}(0)$ emission flux from $(+)$ or deposition flux into $(-)$ the surface water. The gas transfer coefficient $(K)$ is calculated by Wanninkhof (1992), $K=0.31 u_{10}{ }^{2}\left(S c_{\mathrm{Hg}} / 600\right)^{0.5}$, where $u_{10}$ is the wind speed $\left(\mathrm{m} \mathrm{s}^{-1}\right)$ at $10 \mathrm{~m}$ above the sea surface and the $S c_{\mathrm{Hg}}$ is the temperature- and salinity-dependent dimensionless Schmidt number of $\mathrm{Hg}(0)$ for seawater. The $S c_{\mathrm{Hg}}$ is defined as $v / D$, where $v$ is the kinematic viscosity $\left(\mathrm{cm}^{2} \mathrm{~s}^{-1}\right)$ of seawater and $D$ is the aqueous diffusion coefficient $\left(\mathrm{cm}^{2} \mathrm{~s}^{-1}\right)$ of $\mathrm{Hg}(0)$. The $v$ and $D$ are calculated according to Wanninkhof(1992) and Kuss et al. (2009), respectively. $H^{\prime}$ is the dimensionless Henry's law constant: $H^{\prime}=\exp (-2404.3 / T+6.92)$ (Andersson et al. 2008a), where $T$ is the surface water temperature $(\mathrm{K})$.

The degree of saturation $\left(S_{\mathrm{a}}\right)$ of $\operatorname{Hg}(0)$ in surface waters with respect to the atmospheric $\mathrm{Hg}(0)$ is defined as $S_{\mathrm{a}}=\mathrm{Hg}(0)_{\text {water }} H^{\prime} / \mathrm{Hg}(0)_{\text {air }}$. The $S_{\mathrm{a}}$ value greater than 1 indicates the supersaturation of $\operatorname{Hg}(0)$ in surface water and subsequent $\mathrm{Hg}(0)$ emission from sea surface; otherwise, undersaturation is indicated and the $\operatorname{Hg}(0)$ deposition from the atmosphere to ocean occurs.

\section{Results and discussion}

\section{THg in water}

Table 1 presents the summary of $\mathrm{THg}$ in water, $\mathrm{Hg}(0)$ in air and surface water, wind speed, water temperature, saturation of degree of $\operatorname{Hg}(0)$ in surface water $\left(S_{\mathrm{a}}\right)$, and air-sea $\operatorname{Hg}(0)$ fluxes. The concentrations of $\mathrm{THg}$ (remaining $\mathrm{THg}+\mathrm{Hg}(0)$ ) in waters varied from 0.96 to $2.23 \mathrm{ng} \mathrm{L}^{-1}$ with mean concentrations of $1.40 \pm 0.48 \mathrm{ng} \mathrm{L}^{-1}(n=8)$. These concentrations were clearly higher than those in the open oceans, such as the North Atlantic Ocean (0.48 ng L ${ }^{-1}$, Mason et al. 1998) and the North Pacific Ocean ( $\sim 0.2 \mathrm{ng} \mathrm{L}^{-2}$, Laurier et al. 2004), and comparable to those of coast, offshore, and estuary, such as the Yellow Sea (1-3 ng L ${ }^{-1}, \mathrm{Ci}$ et al. 2011b, d) and the Connecticut River Estuary ( $\sim 2 \mathrm{ng} \mathrm{L}^{-1}$, Rolfhus et al. 2003).

During 2003 to 2007, Tseng et al. (2012, 2013) studied the $\mathrm{Hg}$ distribution in air and water in the South East Asia TimeSeries Station (SEATS), which is located in the open water of the SCS and about $6.5^{\circ}(\sim 800 \mathrm{~km})$ further east than our station
Table 1 Range and mean $( \pm \mathrm{SD})$ value of THg in water, $\mathrm{Hg}(0)$ in air and surface water, wind speed, water temperature, saturation of degree of $\mathrm{Hg}(0)$ in surface water $\left(S_{\mathrm{a}}\right)$, and air-sea $\mathrm{Hg}(0)$ flux from 27 January to 8 February 2015 in the Luhuitou fringing reef $\left(18^{\circ} 12.71^{\prime} \mathrm{N}, 109^{\circ} 28.39^{\prime}\right.$ E) of the South China Sea, Sanya City, China

\begin{tabular}{lccccl}
\hline & Min. & Max. & Mean & SD & Number \\
\hline THg in water $\left(\mathrm{ng} \mathrm{L}^{-1}\right)$ & 0.96 & 2.23 & 1.40 & 0.48 & 8 \\
$\mathrm{Hg}(0)$ in air $\left(\mathrm{ng} \mathrm{m}^{-3}\right)$ & 1.88 & 3.22 & 2.34 & 0.26 & 94 \\
$\mathrm{Hg}(0)$ in water $\left(\mathrm{pg} \mathrm{L}^{-1}\right)$ & 17.9 & 101.0 & 53.7 & 18.8 & 187 \\
Wind speed at $10{\mathrm{~m}\left(\mathrm{~m} \mathrm{~s}^{-1}\right)}^{-1}$ & 0.45 & 5.80 & 3.26 & 1.04 & 187 \\
Water temperature $\left({ }^{\circ} \mathrm{C}\right)$ & 19.01 & 26.10 & 22.80 & 1.61 & 187 \\
$S_{\mathrm{a}}$ & 2.46 & 13.86 & 6.96 & 2.50 & 187 \\
$\mathrm{Hg}(0)$ flux $\left(\mathrm{ng} \mathrm{m}^{-2} \mathrm{~h}^{-1}\right)$ & 0.01 & 6.06 & 1.73 & 1.25 & 187 \\
\hline
\end{tabular}

(see Fig. 1 for the location of the SEATS). Fu et al. (2010) also investigated the $\mathrm{Hg}$ distribution in air and water in the northern SCS in the 2007 summer cruise. Compared to the study of Fu et al. (2010), our concentrations were slightly higher than those in the open water $\left(\sim 1 \mathrm{ng} \mathrm{L}^{-1}\right)$ of the northern SCS, but very similar to those offshore $\left(1-2 \mathrm{ng} \mathrm{L}^{-1}\right)$ near the Hainan Island. Notably, our concentrations were very similar to the SEATS in the winter $\left(\sim 1.6 \mathrm{ng} \mathrm{L}^{-1}\right)$, but slightly lower than other seasons (1.8-2.2 $\mathrm{ng} \mathrm{L}^{-1}$, Tseng et al. 2013).

\section{$\mathrm{Hg}(\mathbf{0})$ in atmosphere}

The mean concentrations of atmospheric $\operatorname{Hg}(0)( \pm \mathrm{SD})$ in the study period were $2.34 \pm 0.26 \mathrm{ng} \mathrm{m}^{-3}(n=94)$ with a range of 1.88 to $3.22 \mathrm{ng} \mathrm{m}^{-3}$. These concentrations were significantly higher than those in the Northern Hemisphere background region (1.50-1.75 $\mathrm{ng} \mathrm{m}^{-3}$, Ebinghaus et al. 2002), open oceans of the Southern Hemisphere $\left(1.27 \pm 0.2 \mathrm{ng} \mathrm{m}^{-3}\right.$, Soerensen et al. 2010), the tropical Pacific Ocean (1.08 $\pm 0.17 \mathrm{ng} \mathrm{m}^{-3}$, Wang et al. 2014), and some coast of North America (1.41 $\pm 0.20 \mathrm{ng} \mathrm{m}^{-3}$, Weiss-Penzias et al. 2013) but were comparable to the coast and open water of East Asia, such as the coast of Korea ( $\sim 3-4 \mathrm{ng} \mathrm{m}^{-3}$, Nguyen et al. 2007, 2010), the island of Okinawa (2.04 $\mathrm{ng} \mathrm{m}^{-3}$, Jaffe et al. 2005), and the open water of the Bohai Sea, the Yellow Sea, and the East China Sea ( 2-3 ng m ${ }^{-3}$, Ci et al. 2011a, d, 2015; Wang et al. 2016).

Recently, Lei et al. (2015) measured the total gaseous Hg concentrations (mainly $\mathrm{Hg}(0)$ ) in the Wuzhi Mountain (958 m a.s.1.), which is a forest background region and located in about $80 \mathrm{~km}$ further north than our station (see Fig. 1 for the location of the Wuzhi Mountain). Our concentrations were higher than the annual mean concentrations (1.58 $\pm 0.71 \mathrm{ng} \mathrm{m}^{-3}$ ) of the Wuzhi Mountain but were comparable to its winter concentrations $\left(2.02 \pm 0.53 \mathrm{ng} \mathrm{m}^{-3}\right)$. Our concentrations were also comparable to the northern SCS in the summer of 2007 (2.62 $\mathrm{ng} \mathrm{m}^{-3}$, Fu et al. 2010). Tseng et al. (2012) 
observed a clear seasonality of atmospheric $\operatorname{Hg}(0)$ with low concentrations in summer $\left(2.8 \pm 0.2 \mathrm{ng} \mathrm{m}^{-3}\right)$ and high concentrations in winter $\left(5.7 \pm 0.2 \mathrm{ng} \mathrm{m}^{-3}\right)$ in the SEATS. Clearly, our concentrations were comparable to the summer but significantly lower than the winter in the SEATS. According to the 72-h back-trajectory analysis, Tseng et al. (2012) suggested that the high atmospheric $\mathrm{Hg}(0)$ concentrations in winter were attributed to the northeast monsoon which brought the air masses with enhanced $\mathrm{Hg}(0)$ from continental East Asia. In the period of our study, the prevailing wind direction was also northeastern, but the 72-h back-trajectory analysis showed that, due to the low wind speed $\left(\sim 3 \mathrm{~m} \mathrm{~s}^{-1}\right)$, the sampled air masses mainly originated from the sea surface near the coast of the Southern China $\left(22^{\circ}-26^{\circ} \mathrm{N}\right)$ with little direct anthropogenic $\mathrm{Hg}$ emission (data no shown). Therefore, the significant difference of atmospheric $\mathrm{Hg}(0)$ in winter between our study and that of Tseng et al. (2012) may be due to the sampled air masses originated from different source regions (clean maritime air vs polluted continental air).

\section{$\operatorname{Hg}(0)$ in water}

The mean concentrations of $\operatorname{Hg}(0)$ in surface water were 53.7 $\pm 18.8 \mathrm{pg} \mathrm{L}^{-1}(n=187)$ with a range of 17.9 to $101.0 \mathrm{pg} \mathrm{L}^{-1}$. These concentrations were higher than those in the tropical Pacific Ocean (10-70 pg L ${ }^{-1}$, Kim and Fitzgerald 1986; Mason and Fitzgerald 1993; Soerensen et al. 2014) and comparable to the concentrations of $\mathrm{Hg}(0)$ in the subtropical and tropical Atlantic Ocean ( 10-210 pg L ${ }^{-1}$, Mason and Sullivan 1999; Kuss et al. 2011). Our concentrations were also higher than the annual mean concentrations of some coast (e.g., the coast of the Yellow Sea, $\sim 30 \mathrm{pg} \mathrm{L}^{-1}$, Ci et al. 2011a) and offshore (the Baltic Sea, 10-32 pg L ${ }^{-1}$, Kuss and Schneider 2007; the open water of the Yellow Sea, $\sim 35 \mathrm{pg} \mathrm{L}^{-1}$, Ci et al. 2011b) environments in temperate zone but were comparable to some temperate marine environments in warm seasons with similar THg levels, water temperature, and solar radiation, such as the coast and offshore of the Yellow Sea in summer campaigns ( $\sim 60 \mathrm{pg} \mathrm{L}^{-1}, \mathrm{Ci}$ et al. 2011a, d) and the Island of Corsica in the Mediterranean Sea on June 2004 ( 20$100 \mathrm{pg} \mathrm{L}^{-1}$, Fantozzi et al. 2007).

Tseng et al. (2013) reported a pronounced seasonality of water $\mathrm{Hg}(0)$ in the SEATS with high concentrations in warm seasons and low concentrations in cold seasons. Notably, our concentrations of water $\mathrm{Hg}(0)\left(53.7 \pm 18.8 \mathrm{pg} \mathrm{L}^{-1}\right)$ were higher than those in both the summer $\left(32 \pm 8 \mathrm{pg} \mathrm{L}^{-1}\right)$ and the winter $\left(12 \pm 6 \mathrm{pg} \mathrm{L}^{-1}\right)$ in the SEATS. Our concentrations were also higher than the mean concentrations $\left(36.5 \pm 14.9 \mathrm{pg} \mathrm{L}^{-1}\right)$ of the northern SCS in the summer cruise but were very similar to those of stations near the Hainan Island $\left(\sim 40-80 \mathrm{pg} \mathrm{L}^{-1}\right.$, Fu et al. 2010). Many field measurements also widely reported that the water $\mathrm{Hg}(0)$ concentrations in nearshore environments were generally higher than those in the open water (e.g.,
Mason et al. 2001; Ci et al. 2011d). The field observations and incubation experiments suggest that the special properties of nearshore environment, such as the enhanced THg levels, the estuarine mixing, and the high biological activity, can either promote the production of water $\operatorname{Hg}(0)$ and/or increase the $\operatorname{Hg}(0)$ input to the coastal water (Amyot et al. 1997; Lanzillotta et al. 2002; Rolfhus et al. 2003; Covelli et al. 2008; Fantozzi et al. 2009; Schartup et al. 2015; Ci et al. 2016).

In this study, the mean value of $\mathrm{Hg}(0) / \mathrm{THg}$ ratios was $3.8 \%$. These values were significantly lower than those in open oceans ( $10-50 \%$, e.g., Mason et al. 2001; Soerensen et al. 2013; Schartup et al. 2015) and comparable to concentrations of many coast and offshore environments $(1-5 \%$, e.g., Mason et al. 1999; Ci et al. 2011a, d). It should be noted that our values were slightly higher than those in the northern SCS in the summer cruise (3.0\%, Fu et al. 2010) but significantly higher than those in the winter in the SEATS $(\sim 1 \%)$ and other seasons (1-1.6\%) (Tseng et al. 2013).

As mentioned above, the Luhuitou fringing reef is a shallow coast $(\sim 5 \mathrm{~m})$ and widely covered by corals (Zhang et al. 2013). It is well known that coral reef is one of the most productive marine ecosystems and contains a high level of biodiversity (Gattuso et al. 1998). The high productivity of coral reef ecosystem may favor the production of water $\mathrm{Hg}(0)$ and subsequently increase the $\mathrm{Hg}(0) / \mathrm{THg}$ ratio by two pathways. One is that the biological process of the coral reef ecosystem may directly reduce the $\mathrm{Hg}(\mathrm{II})$ to $\mathrm{Hg}(0)$ via the microbial-mediated $\mathrm{Hg}$ (II) reduction (Fantozzi et al. 2009). The other is that the high productivity of the coral ecosystem alters the water chemistry, for example increasing the organic matter in water column, and thus may promote the $\operatorname{Hg}(0)$ production since the organic matter generally favors the photoreduction of $\mathrm{Hg}$ (II) to $\mathrm{Hg}(0)$ (Costa and Liss 1999; Schartup et al. 2015). Therefore, we suppose that the special property of the Luhuitou fringing reef, particularly the large coverage of corals, may greatly promote the production of $\mathrm{Hg}(0)$ in coastal water, resulting in higher $\operatorname{Hg}(0)$ concentrations and $\operatorname{Hg}(0)$ / THg ratio in coastal water than the open water of the SCS. However, to our best knowledge, there is a lack of investigation of $\mathrm{Hg}$ biogeochemical cycle under the influence of coral reef ecosystem. More targeted and systematic researches are needed in the future.

Figure 2 shows the time series of $\operatorname{Hg}(0)$ data and the measured environmental parameters in the entire study period. As shown in Fig. 2, the $\operatorname{Hg}(0)$ concentrations in surface water were highly variable. In many days of the study period (e.g., 30 January and 7 February), the $\mathrm{Hg}(0)$ concentrations in waters generally paralleled the solar radiation, presented clearly a diurnal variation with low levels before sunrise, increased to and reached peak levels around noon, and then decreased to low levels in the afternoon and nighttime. This similar correlation has been widely reported (e.g., Fantozzi et al. 2007; Ci 


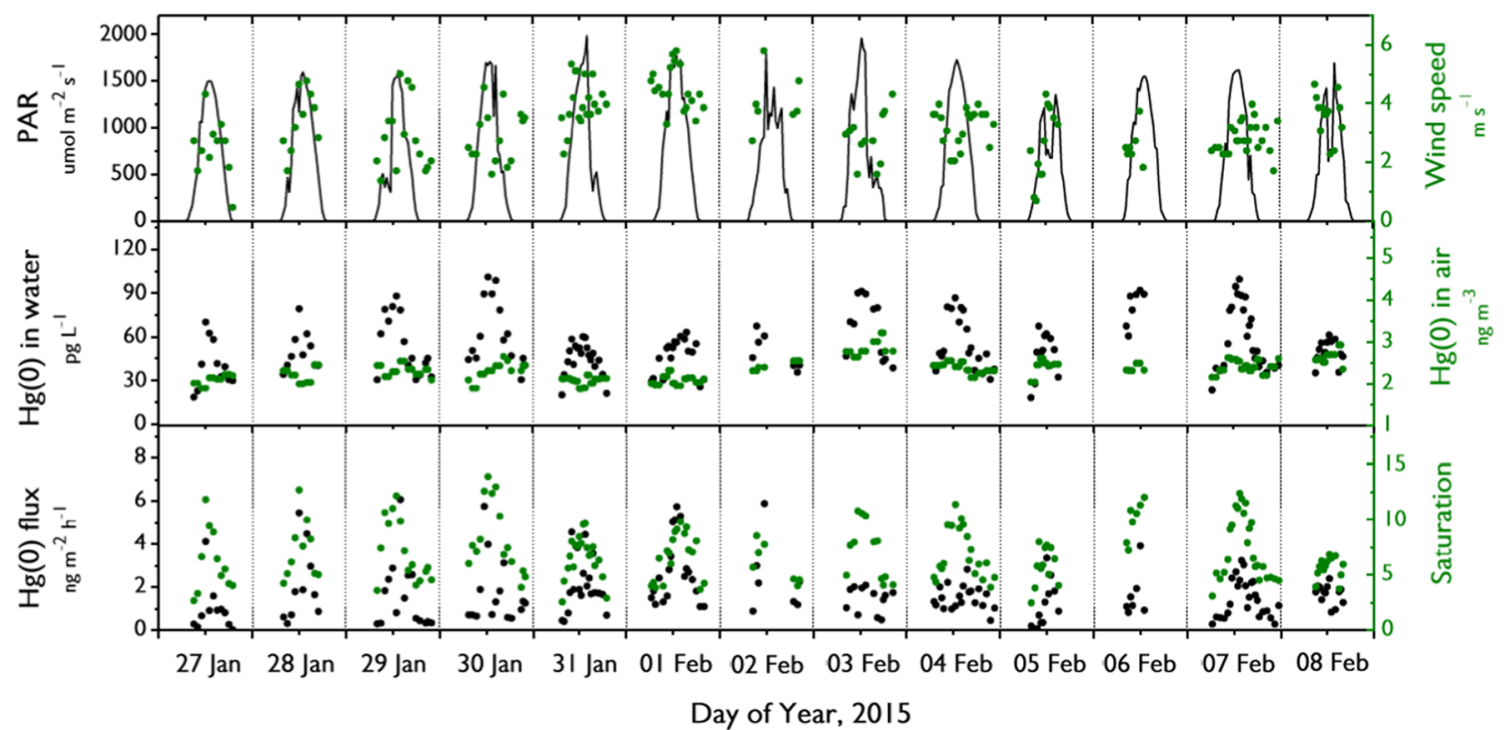

Fig. 2 Time series of $\operatorname{Hg}(0)$ in surface water and air, saturation of degree of $\operatorname{Hg}(0)$ in surface water $\left(S_{\mathrm{a}}\right)$, air-sea $\operatorname{Hg}(0)$ flux, and the measured variables from 27 January to 8 February 2015 in the Luhuitou fringing reef $\left(18^{\circ} 12.71^{\prime} \mathrm{N}, 109^{\circ} 28.39^{\prime}\right.$ E) of the South China Sea, Sanya City, China

et al. 2011a). Linear regression analysis suggested that $\mathrm{Hg}(0)$ concentrations in waters were positively and significantly correlated to the PAR (water $\mathrm{Hg}(0)\left[\mathrm{pg} \mathrm{L}^{-1}\right]=0.0203 \times \mathrm{PAR}$ $\left.\left[\mu \mathrm{mol} \mathrm{m} \mathrm{m}^{-2} \mathrm{~s}^{-1}\right]+38.655, R^{2}=0.42, p<0.001\right)$. This further confirms that the solar radiation is the important controlling factor for the $\mathrm{Hg}(0)$ production in coastal water.

The wind force seems also to greatly regulate the variation of $\operatorname{Hg}(0)$ concentrations in waters in a short time scale. For example, the daytime of 31 January and that of 1 February were cloudless; however, the diurnal variation of water $\operatorname{Hg}(0)$ in these two days was not as pronounced as other cloudless days (e.g., 30 January and 7 February). It is noted that the relatively high wind speed $\left(\sim 4-6 \mathrm{~m} \mathrm{~s}^{-1}\right)$ was recorded in these two days (Fig. 2). Wind force influences the variation of $\operatorname{Hg}(0)$ concentrations mainly in the following three ways. First, the high wind speed increases the $\operatorname{Hg}(0)$ emission from the sea surface under the condition of supersaturate of water $\operatorname{Hg}(0)$ and subsequently reduces the $\operatorname{Hg}(0)$ concentration in water column. Second, the high wind speed promotes the vertical mixing of water and thus reduces the exposure time of water to solar radiation which subsequently reduces the photochemical potential of $\mathrm{Hg}(0)$ production (O'Driscoll et al. 2003; Ci et al. 2011a). Third, unlike deep open oceans, the shallow costal environments provide a large ratio of sediment surface-towater volume and the wind-driven resuspension events induce the elevated vertical mixing of water and then increase the suspended particulate matter of the water column. This process reduces the penetration of solar radiation and also decrease the photochemical potential of $\operatorname{Hg}(0)$ production in water column.

The values of $S_{\mathrm{a}}$ ranged from 2.46 to 13.87 with a mean value of $6.96 \pm 2.50$. Clearly, the $S_{\text {a values were always greater }}$ than 1 , indicating that the surface water was always the source of atmospheric $\mathrm{Hg}(0)$. Our values were comparable to those of the tropical and subtropical oceans, such as the Equatorial Pacific Ocean (0.79-40, Kim and Fitzgerald 1986; Mason and Fitzgerald 1993), the Atlantic Ocean ( 4-20, Mason and Sullivan 1999; Kuss et al. 2011), and many coasts and offshore of the temperate marine environments in warmer seasons, such as the Yellow Sea (4.50-7.80, Ci et al. 2011a, d) and the Mediterranean Sea (6-11, Andersson et al. 2007) in summer. Our values were also comparable to those in the northern SCS in summer (5.34, Fu et al. 2010). However, Tseng et al. (2013) found that the water $\operatorname{Hg}(0)$ in the SEATS in winter was undersaturation $\left(S_{\mathrm{a}}=0.6\right)$ due to the combination of low water $\mathrm{Hg}(0)$ and high atmospheric $\mathrm{Hg}(0)$.

\section{Air-sea $\operatorname{Hg}(0)$ flux}

The air-sea $\operatorname{Hg}(0)$ fluxes in this study were estimated to be $1.73 \pm 1.25 \mathrm{ng} \mathrm{m}^{-2} \mathrm{~h}^{-1}$ with a large range from 0.01 to $6.06 \mathrm{ng} \mathrm{m}^{-2} \mathrm{~h}^{-1}$. As described above, the two-layer gas exchange model is very sensitive to the wind speed. The high variation of $\operatorname{Hg}(0)$ fluxes mainly attributed to the high variation of wind speed. Our fluxes were comparable to the Pacific Ocean (1-3 ng m ${ }^{-2} \mathrm{~h}^{-1}$, Kim and Fitzgerald 1986; Mason and Fitzgerald 1993; Soerensen et al. 2014) and comparable to the subtropical and tropical Atlantic Ocean $\left(0.5-20 \mathrm{ng} \mathrm{m}^{-2} \mathrm{~h}^{-1}\right.$, Mason and Sullivan 1999; Kuss et al. 2011) and many temperate marine environments, such as the Yellow Sea (0.51$18.3 \mathrm{ng} \mathrm{m}^{-2} \mathrm{~h}^{-1}$, Ci et al. 2011a, d, 2015), the Mediterranean Sea (0.84-3.40 $\mathrm{ng} \mathrm{m}^{-2} \mathrm{~h}^{-1}$, Andersson et al. 2007), and the Chesapeake Bay (1.1 $\mathrm{ng} \mathrm{m}^{-2} \mathrm{~h}^{-1}$, Mason et al. 1999).

Our fluxes were lower than those of the northern SCS in the summer cruise $\left(4.5 \pm 3.4 \mathrm{ng} \mathrm{m}^{-2} \mathrm{~h}^{-1}\right)$ since high wind speeds were recorded (Fu et al. 2010). Notably, Tseng et al. (2013) 
observed the undersaturation of seawater $\operatorname{Hg}(0)$ in winter since the high concentrations of atmospheric $\mathrm{Hg}(0)$ and low concentrations of water $\operatorname{Hg}(0)$, inducing the net deposition $\operatorname{Hg}(0)\left(-1.5 \mathrm{ng} \mathrm{m}^{-2} \mathrm{~h}^{-1}\right)$ from the atmosphere to the sea surface. This discrepancy further shows the significantly different $\mathrm{Hg}(0)$ dynamics between the coast and open water of the SCS.

\section{Conclusions}

The measurements of $\operatorname{Hg}(0)$ concentrations in the surface water and air in a typical tropical coast of the SCS showed that the behavior of $\operatorname{Hg}(0)$ was highly dynamic in a short time scale, depending on many environmental parameters. Measurements of $\operatorname{Hg}(0)$ in surface waters showed the pronounced diurnal variation with high concentrations in daytime and low concentrations in nighttime, indicating that the photochemical reduction of $\mathrm{Hg}(\mathrm{II})$ is a fundamental process for the production of $\operatorname{Hg}(0)$. Compared to the previous study, we found the significant difference of $\operatorname{Hg}(0)$ dynamics between the coast and open water of the SCS in winter. We suppose that the unique coastal environment setting in the Luhuitou fringing reef, such as the large coverage of corals, may have important impact on the $\operatorname{Hg}(0)$ production in water, inducing the elevated $\mathrm{Hg}(0)$ concentrations and the $\mathrm{Hg}(0) / \mathrm{THg}$ ratio in coastal water than in the open water of the SCS. More focused and comprehensive researches are needed to explore the effect of coral ecosystem on the Hg biogeochemical cycle in the future.

Acknowledgments This research was funded by the National Key Basic Research Program of China (No. 2013CB430002), National Natural Science Foundation of China (Nos. 41203068, 41573117, 41176066, and 41371461), and Young Scientists Fund of Research Center for Eco-Environmental Sciences, Chinese Academy of Sciences (No. RCEES-QN-20130048F). We thank Prof. Hui Huang and Prof. Weihua Zhou and the staff of the Tropical Marine Biological Research Station (Sanya) of the South China Sea Institute of Oceanology (Guangzhou), Chinese Academy of Sciences, for their assistance.We thank the reviewers for their valuable comments and suggestions.

\section{References}

Amyot M, Gill GA, Morel FMM (1997) Production and loss of dissolved gaseous mercury in coastal seawater. Environ Sci Technol 31:36063611

Andersson ME, Gårdfeldt K, Wängberg I, Sprovieri F, Pirrone N, Lindqvist O (2007) Seasonal and daily variation of mercury evasion at coastal and off shore sites from the Mediterranean Sea. Mar Chem 104:214-226

Andersson ME, Gårdfeldt K, Wängberg I, Strömberg D (2008a) Determination of Henry's law constant for elemental mercury. Chemosphere 73:587-592

Andersson ME, Sommar J, Gårdfeldt K, Lindqvist O (2008b) Enhanced concentrations of dissolved gaseous mercury in the surface waters of the Arctic Ocean. Mar Chem 110:190-194
Christian JR, Verschell MA, Murtugudde R, Busalacchi AJ, McClain CR (2001) Biogeochemical modelling of the tropical Pacific Ocean. I: Seasonal and interannual variability. Deep-Sea Res 49:509-543

Ci ZJ, Zhang XS, Wang ZW (2011a) Elemental mercury in coastal seawater of Yellow Sea, China: temporal variation and air-sea exchange. Atmos Environ 45:183-190

Ci ZJ, Zhang XS, Wang ZW, Niu ZC (2011b) Atmospheric gaseous elemental mercury (GEM) over a coastal/rural site downwind of East China: temporal variation and long-range transport. Atmos Environ 45:2480-2487

Ci ZJ, Zhang XS, Wang ZW, Niu ZC (2011c) Phase speciation of mercury $(\mathrm{Hg})$ in coastal water of the Yellow Sea, China. Mar Chem 126: $250-255$

Ci ZJ, Zhang XS, Wang ZW, Niu ZC, Diao XY, Wang SW (2011d) Distribution and air-sea exchange of mercury $(\mathrm{Hg})$ in the Yellow Sea. Atmos Chem Phys 11:2881-2892

Ci ZJ, Wang CJ, Wang ZW, Zhang XS (2015) Elemental mercury $(\mathrm{Hg}(0))$ in air and surface waters of the Yellow Sea during late spring and late fall 2012: concentration, spatial-temporal distribution and air/sea flux. Chemosphere 119:199-208

Ci ZJ, Zhang XS, Yin YG, Chen JS, Wang SW (2016) Mercury redox chemistry in waters of the eastern Asian seas: from polluted coast to clean open ocean. Environ Sci Technol. doi:10.1021/acs.est. $5 \mathrm{~b} 05372$

Costa M, Liss PS (1999) Photoreduction of mercury in sea water and its possible implications for $\mathrm{Hg}^{0}$ air-sea fluxes. Mar Chem 68:87-95

Covelli S, Faganeli J, De Vittor C, Predonzani S, Acquavita A, Horvat M (2008) Benthic fluxes of mercury species in a lagoon environment (Grado Lagoon, Northern Adriatic Sea, Italy). Appl Geochem 23: 529-546

Ebinghaus R, Kock HH, Coggins AM, Spain TG, Jennings SG, Temme C (2002) Long-term measurements of atmospheric mercury at Mace Head, Irish west coast, between 1995 and 2001. Atmos Environ 36: 5267-5276

Fantozzi L, Ferrara R, Frontini FP, Dini F (2007) Factors influencing the daily behaviour of dissolved gaseous mercury concentration in the Mediterranean Sea. Mar Chem 107:4-12

Fantozzi L, Ferrara R, Frontini FP, Dini F (2009) Dissolved gaseous mercury production in the dark: evidence for the fundamental role of bacteria in different types of Mediterranean water bodies. Sci Total Environ 407:917-924

Fantozzi L, Manca G, Ammoscato I, Pirrone N, Sprovieri F (2013) The cycling and sea-air exchange of mercury in the waters of the Eastern Mediterranean during the 2010 MED-OCEANOR cruise campaign. Sci Total Environ 448:151-162

Ferrara R, Mazzolai B, Lanzillotta E, Nucaro E, Pirrone N (2000) Temporal trends in gaseous mercury evasion from the Mediterranean seawaters. Sci Total Environ 259:183-190

Fitzgerald WF, Gill GA, Kim JP (1984) An Equatorial Pacific Ocean source of atmospheric mercury. Science 224:597-599

Fitzgerald WF, Lamborg CH, Hammerschmidt CR (2007) Marine biogeochemical cycling of mercury. Chem Rev 107:641-662

Fu X, Feng X, Zhang G, Xu W, Li X, Yao H, Liang P, Li J, Sommar J, Yin R, Liu N (2010) Mercury in the marine boundary layer and seawater of the South China Sea: concentrations, sea/air flux, and implication for land outflow. J Geophys Res 115:D06303. doi:10.1029/ 2009JD012958

Gårdfeldt K, Sommar J, Ferrara R, Ceccarini C, Lanzillotta E, Munthe J, Wängberg I, Lindqvist O, Pirrone N, Sprovieri F, Pesenti E, Strömberg D (2003) Evasion of mercury from coastal and open waters of the Atlantic Ocean and the Mediterranean Sea. Atmos Environ 37:73-84

Gattuso J-P, Frankignoulle M, Wollast R (1998) Carbon and carbonate metabolism in coastal aquatic ecosystems. Annu Rev Ecol Syst 29: 405-434 
Gill GA, Fitzgerald WF (1987) Picomolar mercury measurements in seawater and other materials using stannous chloride reduction and two-stage gold amalgamation with gas phase detection. Mar Chem 20:227-243

Gustin MS, Amos HM, Huang J, Miller MB, Heidecorn K (2015) Measuring and modeling mercury in the atmosphere: a critical review. Atmos Chem Phys 15:5697-5713

Jaffe D, Prestbo E, Swartzendruber P, Weiss-Penzias P, Kato S, Takami A, Hatakeyama S, Kajii Y (2005) Export of atmospheric mercury from Asia. Atmos Environ 39:3029-3038

Kim JP, Fitzgerald WF (1986) Sea-air partitioning of mercury in the equatorial Pacific Ocean. Science 231:1131-1133

Kuss J, Schneider B (2007) Variability of the gaseous elemental mercury sea-air flux of the Baltic Sea. Environ Sci Technol 41:8018-8023

Kuss J, Holzmann J, Ludwig R (2009) An elemental mercury diffusion coefficient for natural waters determined by molecular dynamics simulation. Environ Sci Technol 43:3183-3186

Kuss J, Zülicke C, Pohl C, Schneider B (2011) Atlantic mercury emission determined from continuous analysis of the elemental mercury seaair concentration difference within transects between $50^{\circ} \mathrm{N}$ and $50^{\circ}$ S. Global Biogeochem Cycles, 25. doi: 10.1029/2010GB003998.

Lanzillotta E, Ceccarini C, Ferrara R (2002) Photo-induced formation of dissolved gaseous mercury in coastal and offshore seawater of the Mediterranean basin. Sci Total Environ 300:179-187

Laurier FJG, Mason RP, Gill GA, Whalin L (2004) Mercury distributions in the North Pacific Ocean-20 years of observations. Mar Chem 90:3-19

Lei YT, Liu M, Chen LG, Xie DH, Lin DZ, Zhao MJ, Zhang YQ, Sun JR (2015) Variation characteristics of total gaseous mercury at Wuzhi Mountain (Wuzhishan) background station in Hainan. Environ Sci 36:817-823 (in Chinese with English abstract)

Mason RP, Fitzgerald WF (1993) The distribution and biogeochemical cycling of mercury in the Equatorial Pacific Ocean. Deep-Sea Res 40:1897-1924

Mason RP, Sullivan KA (1999) The distribution and speciation of mercury in the South and Equatorial Atlantic. Deep-Sea Res 46:937956

Mason RP, Rolfhus KR, Fitzgerald WF (1995) Methylated and elemental mercury cycling in surface and deep ocean waters of the North Atlantic. Water Air Soil Pollut 80:665-677

Mason RP, Rolfhus KR, Fitzgerald WF (1998) Mercury in the North Atlantic. Mar Chem 61:37-53

Mason RP, Lawson NM, Lawrence AL, Leaner JJ, Lee JG, Sheu GR (1999) Mercury in the Chesapeake Bay. Mar Chem 65:77-96

Mason RP, Lawson NM, Sheu G-R (2001) Mercury in the Atlantic Ocean: factors controlling air-sea exchange of mercury and its distribution in the upper waters. Deep-Sea Res 48:2829-2853

Mason RP, Choi AL, Fitzgerald WF, Hammerschmidt CR, Lamborg CH, Soerensen AL, Sunderland EM (2012) Mercury biogeochemical cycling in the ocean and policy implications. Environ Res 119: $101-117$

Nguyen HT, Kim KH, Kim MY, Hong S, Youn YH, Shon ZH, Lee JS (2007) Monitoring of atmospheric mercury at a global atmospheric watch (GAW) site on An-Myun Island, Korea. Water Air Soil Pollut 185:149-164

Nguyen HT, Kim MY, Kim KH (2010) The influence of long-range transport on atmospheric mercury on Jeju Island, Korea. Sci Total Environ 408:1295-1307

O'Driscoll NJ, Beauchamp S, Siciliano SD, Rencz AN, Lean DRS (2003) Continuous analysis of dissolved gaseous mercury (DGM) and mercury flux in two freshwater lakes in Kejimkujik Park, Nova Scotia: evaluating mercury flux models with quantitative data. Environ Sci Technol 37:2226-2235
Qureshi A, O'Driscoll NJ, MacLeod M, Neuhold YM, Hungerbühler K (2010) Photoreactions of mercury in surface ocean water: gross reaction kinetics and possible pathways. Environ Sci Technol 44: 644-649

Qureshi A, MacLeod M, Sunderland E, Hungerbühler K (2012) Exchange of elemental mercury between the oceans and the atmosphere. In: Liu GL, Cai Y, O'Driscoll N (eds) Environmental chemistry and toxicology of mercury. John Wiley \& Sons, USA

Rolfhus KR, Fitzgerald WF (2004) Mechanisms and temporal variability of dissolved gaseous mercury production in coastal seawater. Mar Chem 90:125-136

Rolfhus KR, Lamborg CH, Fitzgerald WF, Balcom PH (2003) Evidence for enhanced mercury reactivity in response to estuarine mixing. J Geophys Res 108:3353

Schartup AT, Ndu UC, Balcom PH, Mason RP, Sunderland EM (2015) Contrasting effects of marine and terrestrially derived dissolved organic matter on mercury speciation and bioavailability in seawater. Environ Sci Technol 49:5965-5972

Soerensen AL, Skov H, Jacob DJ, Soerensen BT, Johnson MS (2010) Global concentrations of gaseous elemental mercury and reactive gaseous mercury in the marine boundary layer. Environ Sci Technol 44:7425-7430

Soerensen AL, Mason RP, Balcom PH, Sunderland EM (2013) Drivers of surface ocean mercury concentrations and air-sea exchange in the West Atlantic Ocean. Environ Sci Technol 47:7757-7765

Soerensen AL, Mason RP, Balcom PH, Jacob DJ, Zhang YX, Kuss J, Sunderland EM (2014) Elemental mercury concentrations and fluxes in the tropical atmosphere and ocean. Environ Sci Technol 48:11312-11319

Tseng CM, Liu CS, Lamborg C (2012) Seasonal changes in gaseous elemental mercury in relation to monsoon cycling over the Northern South China Sea. Atmos Chem Phys 12:7341-7350

Tseng CM, Lamborg CH, Hsu SC (2013) A unique seasonal pattern in dissolved elemental mercury in the South China Sea, a tropical and monsoon-dominated marginal sea. Geophys Res Lett 40:167-172

USEPA (1999) Compendium of methods for the determination of inorganic compounds in ambient air. Chapter IO-5: sampling and analysis for atmospheric mercury. EPA/625/R-96/010a.

USEPA (2002) Method 1631, Revision E: mercury in water by oxidation, purge and trap, and cold vapor atomic fluorescence spectrometry. EPA-821-R-02-019.

Wang F, Saiz-Lopez A, Mahajan AS, Gómez Martín JC, Armstrong D, Lemes M, Hay T, Prados-Roman C (2014) Enhanced production of oxidised mercury over the tropical Pacific Ocean: a key missing oxidation pathway. Atmos Chem Phys 14:1323-1335

Wang CJ, Wang ZW, Ci ZJ, Zhang XS, Tang X (2016) Spatial-temporal distributions of gaseous element mercury and particulate mercury in the Asian marine boundary layer. Atmos Environ 126:107-116

Wanninkhof R (1992) Relationship between wind speed and sea exchange over the ocean. J Geophys Res 97:7373-7382

Weiss-Penzias PS, Williams EJ, Lerner BM, Bates TS, Gaston C, Prather K, Vlasenko A, Li SM (2013) Shipboard measurements of gaseous elemental mercury along the coast of Central and Southern California. J Geophys Res 118:208-219

Whalin L, Kim EH, Mason R (2007) Factors influencing the oxidation, reduction, methylation and demethylation of mercury species in coastal waters. Mar Chem 107:278-294

Zhang CL, Huang H, Ye C, Huang LM, Li XB, Lian JS, Liu S (2013) Diurnal and seasonal variations of carbonate system parameters on Luhuitou fringing reef, Sanya Bay, Hainan Island, South China. Sea Deep-Sea Res 96:65-74 